\title{
VIBRATION CHARACTERISTICS OF THE ROTATING DENTAL INSTRUMENT
}

\author{
E. E. HENRY, M.S., AND F. A. PEYTON, D.Sc. \\ School of Dentistry, Dniversity of Michigan, Ann Arbor, Mich.
}

\section{INTRODUCTION}

$\mathrm{P}$ ATIENT discomfort in restorative dentistry has been attributed mainly to the two factors of heat generation and the vibration produced during the cutting operation on the tooth. A review of the literature, however, gives little information on either the extent or chief source of vibrations.

Gabel reported that the chisel produced the least pain of any instrument used to cut dentin. While the reason for this is not clear, Gabel speculated that it is due in part to the lack of vibration and noise and to a small heat production. ${ }^{1}$ Braceland ${ }^{2}$ referred to the work of Best, ${ }^{3}$ in which he described the relationship of vibration to pain, and pointed out that the dental engine frequently starts painful, annoying stimuli to bring about a reaction of aversion on the part of the patient.

In a direct attempt to measure the nerve reaction set up by vibratory stimuli applied to the teeth, Pfaffman made certain interesting observations. ${ }^{4}$ Electrically controlled sinusoidal waves, checked oscillographically, were applied to cats' teeth. Nerve endings were placed between plates and the nerve response recorded on the oscillograph. "Spikes" resulted as a nervous reaction on the oscilloscope, which continued after the stimulus was removed. The nerve responded faster and more intensely to high frequencies, but the nervous reaction died faster than the response to low frequency. When the initial shock was over, the nerve set up a vibration frequency identical with the impulse. This observation is of some interest in the study of vibrations produced by the rotating dental instrument.

The work reported by Walsh and Symmons ${ }^{5}$ concluded that (1) the upper limit of vibration perception is about 600 C.P.S., (2) a region of "maximum unpleasantness" exists between 150 C.P.S., and 200 C.P.S. and (3) the dental engine and handpiece produce a dominant vibration at about 100 C.P.S. Their first two conclusions are interesting in that they limit the field of vibration that should be studied. The third conclusion was arrived at from data obtained from patient reaction and from values obtained by using a rigidly mounted handpiece to cut away the surface of a brass slug, mounted in a vertical cylinder.

'These references indicate that vibration and noise are a source of patient discomfort and show that only little work has been done on research in any aspect of the subject of vibrations resulting from dental operations.

It can be demonstrated that the vibrations produced by the rotating dental bur are in part a function of the material being cut, and the harder the

This investigation was supported by a research grant project (D-47c) from the National Dental Research Institute, U. S. Public Health Service.

Presented to the Dental Materials Group at the Twenty-seventh General Meeting of the International Association for Dental Research, French Lick Springs, Ind., March, 1950.

Received for publication, April 10, 1950. 
material, the higher the harmonic content of the vibration. The choice of the material to be cut and the method of mounting the sample, therefore, is of primary importance in laboratory studies of this type. It is suspected that only relative or comparative values can be obtained from measurements on any material other than natural teeth supported by the tissues of the mouth.

It should be stated, therefore, that the results being reported at this time were produced under the laboratory conditions stipulated, and should be considered as typical values for the condition under which the test was made. This study should be considered as a comparison of vibrations produced by various instruments, and only as an indication of the vibrations experienced when cutting teeth in the mouth. Studies have been initiated in which measurements are being recorded of vibrations resulting from typical cavity preparations in teeth in the mouth.

\section{PURPOSE OF STUDY}

It was the purpose in this study to examine in a comparative fashion the vibrations produced by prevailing standard dental equipment, using various types of accepted cutting instruments, operated at speeds and applied pressures that are varied over the usual practical operating range for such equipment. No effort has been made to include measurements on equipment operated at exceptionally high speeds or other experimental conditions which would involve equipment of a special design. Only typical values are being reported at this time and no effort is made to report in detail all data thus far obtained. Some general correlations have been observed between the heat generated and the vibrations produced during the cutting operation. The results obtained from a study made of the vibration characteristics resulting from the use of the gas-propelled abrasive in eavity preparation will be described briefly.

\section{METHOD OF TEST}

The vibrations reported are those produced in a block of ivory (of $1 \mathrm{~cm}$. square cross section and $5 \mathrm{~cm}$. long) attached to the platform of an ordinary spring balance scale. The handpiece was pivoted on a knife edge behind the knurled portion of the sheath, with the side of the bur resting on the top of a block of ivory. The engine and handpiece were operated at three different speeds in both the forward and reverse directions for each of five weights applied to the handpiece. The operating speeds were developed by making divisions at approximately one-third of the are of movement of the foot control for the engine, in each direction from the neutral position. The measured prevailing speeds were approximately 1100, 2300 and 3800 r.p.m. Both forward and reverse direetions of operation were studied to determine certain fundamental characteristics of operation which are not revealed by operating in one direction only. The weights applied were $200 \mathrm{Gm}$., $500 \mathrm{Gm} ., 1 \mathrm{~kg}$., 11/2 kg., and $2 \mathrm{~kg}$., which gave a load of approximately $1 / 4 \mathrm{lb}$., $3 / 4 \mathrm{lb}$., 11/2 lbs., $2 \mathrm{lbs}$., and $3 \mathrm{lbs}$. on the spring balance scale.

A Pickering magnetic reluctance type phonographic pick up was placed in a record player tone arm with the needle of the pick up resting on the ivory 
block. In this pick up was produced an electrical voltage which when calibrated for various responses has an amplitude-time relationship corresponding to the vibration in the ivory block.

This voltage was amplified and led to a eathode-ray oseilloscope, giving a visual record which was then photographed. The photographed trace was projected on a screen and amplified until the projected period of oscillation, or pattern, was $40 \mathrm{~cm}$. wide. This projected trace pattern was analyzed through the use of a Coradi analyzer. The analyzer gives the amplitudes of sine waves at the fundamental frequency and at frequencies that are multiples of the fundamental frequency. When superimposed upon each other these waves produced the complex vibratory wave. (This type of analysis is known by the name Fourier analysis or Fourier series analysis.) In the beginning of this work a General Radio sound analyzer (Type $760 \mathrm{~A}$-serial 161) was connected electrically in parallel with the oscilloseope. To correlate theoretical analysis with actual vibrations, an unloaded handpiece, a handpiece using a round bur, fissure bur, and carborundum stone, were studied when cutting a block of ivory. It was found throughout this initial study that the vibration components are in harmonies validating the form of analysis that was used.

In order to make direct comparisons of different operating conditions with regard to the frequencies and amplitudes of the various fundamental and harmonic waves observed, a photograph of a sine wave of known frequency and amplitude was taken immediately after the trace of the vibratory wave. For this sine wave the oseilloscope control settings were identical with the settings used for the vibratory wave. The photographed oscillator trace (sine wave) was also projected and the amplitude measured. The amplitudes of the fundamental and harmonic waves presented in the tables of this report are the readings obtained from the Coradi analyzer as measured in centimeters, and modified or related to a common projected oscillator trace of $25 \mathrm{~cm}$. amplitude.

\section{VIBRATIONS OBSERVED}

In Table I are shown the components of the vibrations of the handpiece alone, which show the side-to-side oscillations of the handpiece at the collet end. To determine these vibrations, the handpiece was wrapped in sponge rubber to resemble the resilieney of the hand grip, and then held in a clamp near the end of the knurled portion of the sheath, opposite to the collet. The needle of the

TABLE I

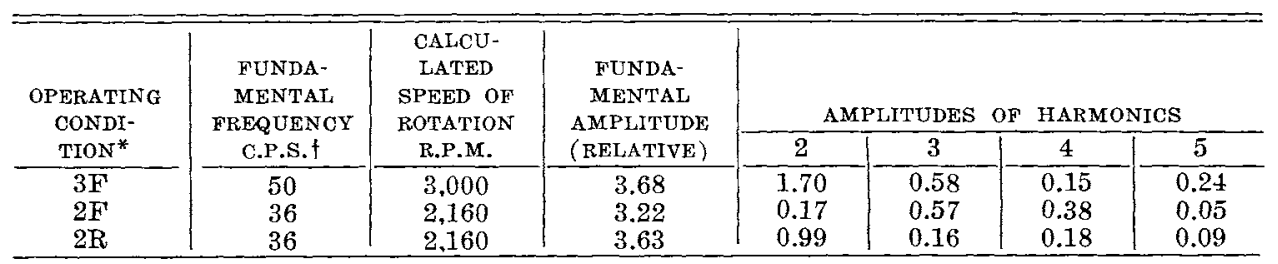

$* 3 F=3810$ r.p.m. forward.

$2 \mathrm{~F}=2139$ r.p.m. forward.

$2 \mathrm{R}=2175$ r.p.m. reverse.

tC.P.S. $=$ cycles per second. 
pick up was placed in contact with the sheath at the collet end, in such a way as to record the sidewise oscillations. No data are presented to show the end-thrust vibrations of the handpiece. The operating conditions noted are $3 \mathrm{~F}$ (Speed 3, forward), $2 \mathrm{~F}$, and $2 \mathrm{R}$ (Speed 2, reverse).

It can be seen from this table that the fundamental frequency of vibration in cycles per second changes with operating speed. It is likewise observed that the fundamental vibration wave occurs at the speed of rotation of the handpiece shaft, as shown by multiplying the fundamental frequency by 60 . These data indicate also that a portion of the vibrations observed when cutting with a bur may in part be produced either by the engine, transmitted through the metal arm, or by the rotation of the handpiece shaft, and magnified by the cutting action of the bur.

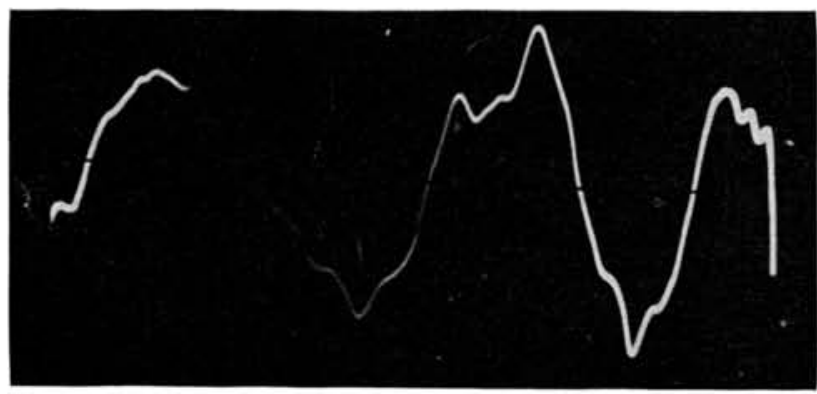

Fig. 1.-Character of vibration wave produced by handpiece alone, speed 2, forward.

From Table $I$ it is observed also that the amplitude of the fundamental vibration is larger than any harmonic, by a ratio of at least 2 to 1 , and that the relative amplitudes of the harmonies decrease rapidly as they are extended beyond the second. The data presented here are for the first five harmonics, although calculations have been carried to the tenth. As will be seen in subsequent figures, the amplitudes of the sixth to tenth harmonies are small. The largest amplitude value of the fundamental vibration is 3.68 for Speed 3 operated in the forward direction. The character of this wave is shown in Fig. 1.

An additional source of vibration which has been observed is that produced by the splice in the engine belt. While no effort has been made to analyze in detail the vibration from this source, it has been detected and recorded in these studies by a characteristic shape of the vibration curve which is repeated at definite intervals. The effect was most pronounced at approximately 2,100 r.p.m., at which speed it can be shown to oceur once in each 1.26 seconds, when using a belt 128 inches long on a handpiece pulley of approximately one inch in diameter.

\section{THE EFFECT OF DIFFERENT BURS}

The results obtained from the study of five burs, including the No. 557 fissure bur, No. 37 and No. 39 inverted cone burs, and No. 2 and No. 4 round burs are shown by the values given in Tables II, III, and IV. In Fig. 2 is shown the relative amplitude of the various harmonics to the tenth, for all five burs 
operated at speed $3 \mathrm{~F}$ (approximately 3,800 r.p.m.) and a pressure of $1 \frac{1}{2} \mathrm{lbs}$. Values are plotted in Fig. 3 to show the relative amplitude of the same harmonics resulting from all five burs operated at speed $2 \mathrm{~F}$ (approximately 2,300 r.p.m.)

TABLE II

\begin{tabular}{|c|c|c|c|c|c|c|c|c|c|}
\hline \multirow[b]{2}{*}{ BUR } & \multirow{2}{*}{$\begin{array}{l}\text { OPERAT- } \\
\text { ING CON- } \\
\text { DITION* }\end{array}$} & \multirow{2}{*}{$\begin{array}{l}\text { LOAD } \\
\text { IN } \\
\text { GRAMS }\end{array}$} & \multirow{2}{*}{$\begin{array}{c}\text { FUNDA- } \\
\text { MENTAL } \\
\text { FRE- } \\
\text { QUENCY }\end{array}$} & \multirow{2}{*}{$\begin{array}{l}\text { CALCU- } \\
\text { LATED } \\
\text { SPEED OF } \\
\text { ROTATION }\end{array}$} & \multirow{2}{*}{$\begin{array}{l}\text { FUNDA- } \\
\text { MENTAL } \\
\text { AMPLI- } \\
\text { TUDE }\end{array}$} & \multicolumn{2}{|c|}{ AMPLITUDES } & \multicolumn{2}{|c|}{ HARMONICS } \\
\hline & & & & & & 2 & 3 & 4 & 5 \\
\hline 557 & $\begin{array}{l}2 \mathrm{R} \\
2 \mathrm{~F} \\
3 \mathrm{~F}\end{array}$ & 200 & $\begin{array}{l}25.6 \\
-\end{array}$ & $\begin{array}{l}1,535 \\
2,560 \\
3,460\end{array}$ & $\begin{array}{l}9.15 \\
9.22 \\
2.01\end{array}$ & $\begin{array}{l}0.78 \\
1.72 \\
2.28\end{array}$ & $\begin{array}{l}1.67 \\
1.41 \\
1.55\end{array}$ & $\begin{array}{l}0.37 \\
0.74 \\
0.75\end{array}$ & $\begin{array}{l}0.41 \\
1.36 \\
0.28\end{array}$ \\
\hline 557 & $\begin{array}{l}2 \mathrm{R} \\
3 \mathrm{~F}\end{array}$ & 500 & $\begin{array}{l}24.4 \\
42.7\end{array}$ & $\begin{array}{l}1,465 \\
2,560\end{array}$ & $\begin{array}{c}2.48 \\
12.7\end{array}$ & $\begin{array}{l}3.25 \\
2.2\end{array}$ & $\begin{array}{l}2.26 \\
1.13\end{array}$ & $\begin{array}{l}1.05 \\
0.56\end{array}$ & $\begin{array}{l}0.81 \\
0.35\end{array}$ \\
\hline 557 & $\begin{array}{l}2 \mathrm{R} \\
2 \mathrm{~F} \\
3 \mathrm{~F}\end{array}$ & 1,000 & $\begin{array}{l}24.4 \\
19.8 \\
38.8\end{array}$ & $\begin{array}{l}1,465 \\
1.190 \\
2,325\end{array}$ & $\begin{array}{l}9.0 \\
8.33 \\
6.87\end{array}$ & $\begin{array}{l}0.43 \\
1.28 \\
2.54\end{array}$ & $\begin{array}{l}2.6 \\
2.55 \\
1.09\end{array}$ & $\begin{array}{l}0.64 \\
0.48 \\
0.89\end{array}$ & $\begin{array}{l}0.34 \\
0.21 \\
0.17\end{array}$ \\
\hline 557 & $\begin{array}{l}2 \mathrm{R} \\
2 \mathrm{~F} \\
3 \mathrm{~F}\end{array}$ & 1,500 & $\begin{array}{l}23.1 \\
22.8 \\
37.4\end{array}$ & $\begin{array}{l}1,390 \\
1,370 \\
2.245\end{array}$ & $\begin{array}{l}6.42 \\
1.63 \\
1.11\end{array}$ & $\begin{array}{l}1.68 \\
3.89 \\
0.67\end{array}$ & $\begin{array}{l}1.09 \\
0.26 \\
0.89\end{array}$ & $\begin{array}{l}0.58 \\
0.47 \\
0.37\end{array}$ & $\begin{array}{l}0.72 \\
0.42 \\
0.50\end{array}$ \\
\hline
\end{tabular}

* Essentially same speed condition as in Table I.

TABLE III

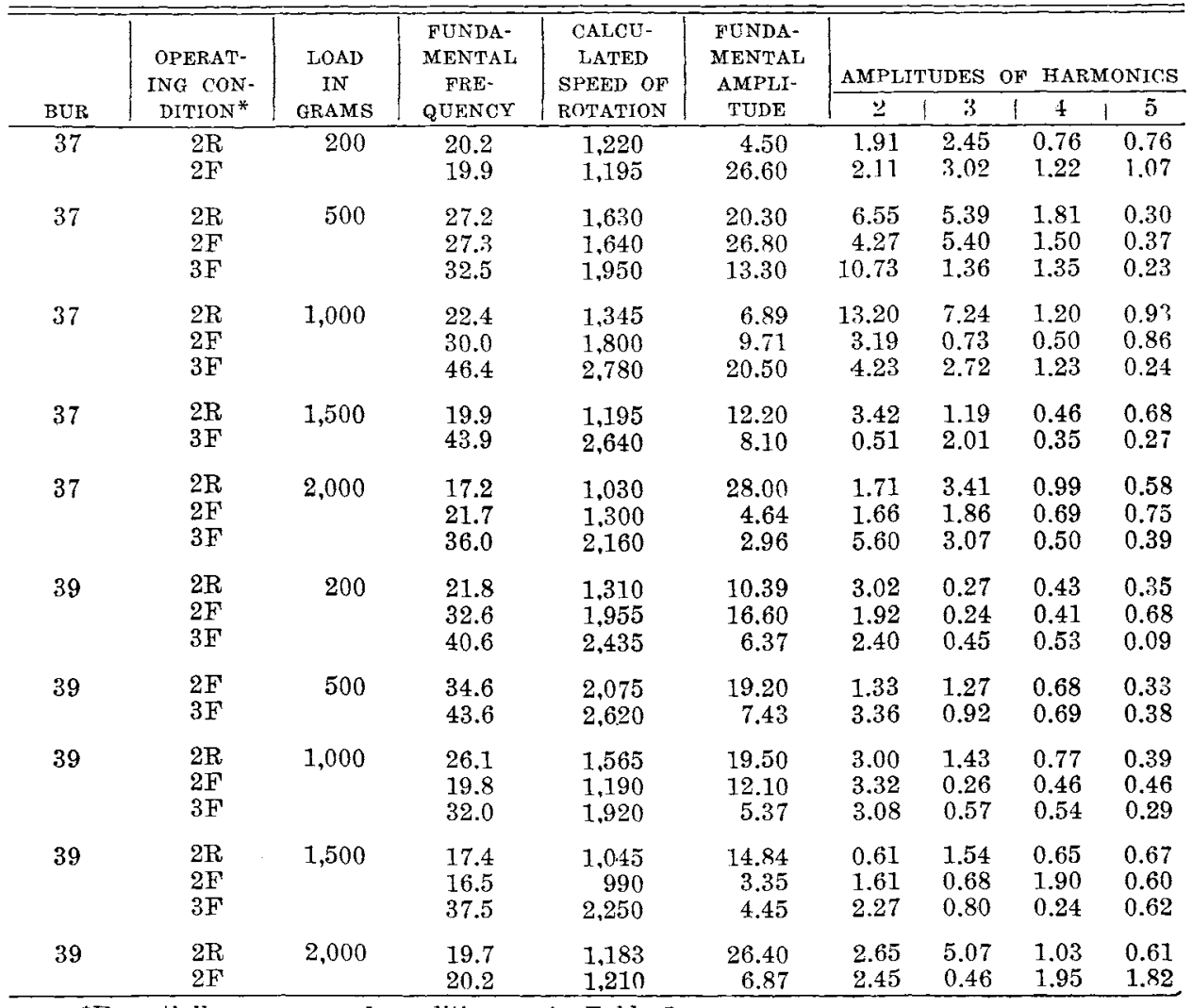

* Essentially same speed condition as in Table 1 . 
and a pressure of $1 / 4 \mathrm{lb}$. These two figures show graphically that the amplitude of the fundamental vibration is predominantly greater than the amplitude of the harmonic vibrations, and the relative value of each harmonic decreases as the number of the harmonic increases.

TABLE IV

\begin{tabular}{|c|c|c|c|c|c|c|c|c|c|}
\hline \multirow[b]{2}{*}{ BUR } & \multirow{2}{*}{$\begin{array}{c}\text { OPERATING } \\
\text { CONDI- } \\
\text { TION* }\end{array}$} & \multirow{2}{*}{$\begin{array}{l}\text { LOAD IN } \\
\text { GRAMS }\end{array}$} & \multirow{2}{*}{$\begin{array}{l}\text { FUNDA- } \\
\text { MENTAL } \\
\text { FRE- } \\
\text { QUENCY }\end{array}$} & \multirow{2}{*}{$\begin{array}{l}\text { CALCU- } \\
\text { LATED } \\
\text { SPEED OF } \\
\text { ROTATION }\end{array}$} & \multirow{2}{*}{$\begin{array}{c}\text { FUNDA- } \\
\text { MENTAL } \\
\text { AMPLITUDE }\end{array}$} & \multicolumn{2}{|c|}{ AMPLITUDES } & \multicolumn{2}{|c|}{ HARMONICS } \\
\hline & & & & & & 2 & 3 & 14 & 5 \\
\hline 2 & $\begin{array}{l}2 \mathrm{R} \\
2 \mathrm{~F} \\
3 \mathrm{~F}\end{array}$ & 200 & $\begin{array}{l}42.0 \\
39.6 \\
53.0\end{array}$ & $\begin{array}{l}2,520 \\
2,370 \\
3.180\end{array}$ & $\begin{array}{r}7.5 \\
16.9 \\
12.8\end{array}$ & $\begin{array}{l}4.10 \\
9.80 \\
0.49\end{array}$ & $\begin{array}{l}1.06 \\
2.09 \\
1.44\end{array}$ & $\begin{array}{l}1.22 \\
2.54 \\
0.93\end{array}$ & $\begin{array}{l}1.74 \\
0.26 \\
0.34\end{array}$ \\
\hline 2 & $\begin{array}{l}2 \mathrm{R} \\
2 \mathrm{~F}\end{array}$ & 500 & $\begin{array}{l}49.4 \\
41.6\end{array}$ & $\begin{array}{l}2,965 \\
2,490\end{array}$ & $\begin{array}{l}18.8 \\
15.0\end{array}$ & $\begin{array}{l}2.01 \\
3.80\end{array}$ & $\begin{array}{l}0.88 \\
0.22\end{array}$ & $\begin{array}{l}0.04 \\
0.18\end{array}$ & $\begin{array}{l}0.25 \\
0.19\end{array}$ \\
\hline 2 & $\begin{array}{l}2 F \\
3 F\end{array}$ & 1.000 & $\begin{array}{l}48.8 \\
64.0\end{array}$ & $\begin{array}{l}2,935 \\
3,840\end{array}$ & $\begin{array}{r}23.7 \\
5.2\end{array}$ & $\begin{array}{l}1.00 \\
1.32\end{array}$ & $\begin{array}{l}0.52 \\
0.44\end{array}$ & $\begin{array}{l}0.30 \\
0.08\end{array}$ & $\begin{array}{l}0.74 \\
0.06\end{array}$ \\
\hline 2 & $\begin{array}{l}2 \mathrm{R} \\
2 \mathrm{~F} \\
3 \mathrm{~F}\end{array}$ & 1,500 & $\begin{array}{l}38.5 \\
49.5 \\
47.9\end{array}$ & $\begin{array}{l}2,310 \\
2,970 \\
2,870\end{array}$ & $\begin{array}{c}17.0 \\
14.8 \\
3.78\end{array}$ & $\begin{array}{l}5.20 \\
1.76 \\
1.14\end{array}$ & $\begin{array}{l}0.70 \\
0.40 \\
0.18\end{array}$ & $\begin{array}{l}0.40 \\
0.06 \\
0.04\end{array}$ & $\begin{array}{l}0.43 \\
0.03 \\
0.10\end{array}$ \\
\hline 2 & $\begin{array}{l}2 F \\
3 F\end{array}$ & 2,000 & $\begin{array}{l}39.7 \\
58.5\end{array}$ & $\begin{array}{l}2,380 \\
3,510\end{array}$ & $\begin{array}{l}2.1 \\
6.9\end{array}$ & $\begin{array}{l}1.06 \\
2.90\end{array}$ & $\begin{array}{l}0.44 \\
0.21\end{array}$ & $\begin{array}{l}0.22 \\
0.26\end{array}$ & $\begin{array}{l}0.04 \\
0.02\end{array}$ \\
\hline 4 & $\begin{array}{l}2 \mathrm{R} \\
2 \mathrm{~F} \\
3 \mathrm{~F}\end{array}$ & 200 & $\begin{array}{l}51.9 \\
40.2 \\
47.8\end{array}$ & $\begin{array}{l}3,120 \\
2,410 \\
-\end{array}$ & $\begin{array}{l}25.5 \\
13.6 \\
12.7\end{array}$ & $\begin{array}{l}0.42 \\
0.90 \\
1.01\end{array}$ & $\begin{array}{l}0.32 \\
0.89 \\
0.22\end{array}$ & $\begin{array}{l}0.13 \\
0.19 \\
0.19\end{array}$ & $\begin{array}{l}0.13 \\
0.27 \\
0.08\end{array}$ \\
\hline 4 & $\begin{array}{l}2 \mathrm{R} \\
2 \mathrm{~F} \\
3 \mathrm{~F}\end{array}$ & 500 & $\begin{array}{l}50.0 \\
45.0\end{array}$ & $\begin{array}{l}3,000 \\
2,700 \\
-\end{array}$ & $\begin{array}{l}23.2 \\
19.1 \\
21.0\end{array}$ & $\begin{array}{l}1.78 \\
2.48 \\
3.77\end{array}$ & $\begin{array}{l}1.03 \\
1.01 \\
0.97\end{array}$ & $\begin{array}{l}0.43 \\
0.16 \\
0.42\end{array}$ & $\begin{array}{l}0.32 \\
0.15 \\
0.14\end{array}$ \\
\hline 4 & $\begin{array}{l}2 \mathrm{R} \\
2 \mathrm{~F} \\
3 \mathrm{~F}\end{array}$ & 1,000 & $\begin{array}{l}63.0 \\
47.6 \\
61.0\end{array}$ & $\begin{array}{l}\overline{2,850} \\
3.660\end{array}$ & $\begin{array}{l}12.8 \\
8.45 \\
19.5\end{array}$ & $\begin{array}{l}2.47 \\
0.88 \\
5.27\end{array}$ & $\begin{array}{l}0.55 \\
1.87 \\
2.15\end{array}$ & $\begin{array}{l}2.39 \\
0.73 \\
1.56\end{array}$ & $\begin{array}{l}0.20 \\
0.18 \\
0.78\end{array}$ \\
\hline 4 & $\begin{array}{l}2 F \\
3 F\end{array}$ & 1,500 & $\begin{array}{l}44.3 \\
77.8\end{array}$ & $\begin{array}{l}2,660 \\
4,670\end{array}$ & $\begin{array}{c}9.62 \\
10.4\end{array}$ & $\begin{array}{l}3.05 \\
1.18\end{array}$ & $\begin{array}{l}1.61 \\
0.83\end{array}$ & $\begin{array}{l}0.43 \\
0.23\end{array}$ & $\begin{array}{l}0.24 \\
0.25\end{array}$ \\
\hline 4 & $\begin{array}{l}2 F \\
3 F\end{array}$ & 2,000 & $\begin{array}{l}49.2 \\
82.4 \\
\end{array}$ & $\begin{array}{l}2.940 \\
4.940 \\
\end{array}$ & $\begin{array}{r}7.5 \\
12.7 \\
\end{array}$ & $\begin{array}{l}1.57 \\
0.81 \\
\end{array}$ & $\begin{array}{l}0.58 \\
0.19 \\
\end{array}$ & $\begin{array}{l}0.16 \\
0.13 \\
\end{array}$ & $\begin{array}{l}0.05 \\
0.07 \\
\end{array}$ \\
\hline
\end{tabular}

*Essentially same speed condition as in Table $\mathrm{I}$.

The curves in Fig. 4 show the relative amplitude of the fundamental vibration in relation to the pressure applied for the five burs studied. They show in general that, as the pressure is increased, the amplitude of the fundamental vibration decreases when the bur is driven in the forward direction and increases as the bur is driven in the reverse direction (lower half of Fig. 4). There appears to be some tendency for the fundamental vibration to increase as the bur size is increased, although more study is desirable to establish definitely such a relationship.

The relative amplitude of the third harmonic as a function of the pressure applied is shown in Fig. 5. In general, much the same conclusions can be drawn from these curves, with a few exceptions, as from those shown in Fig. 4, except that the changes are not so pronounced.

In Fig. 6 are represented the same data as in Fig. 4, but replotted to show the relative amplitude of the fundamental vibration as compared to the speed of 


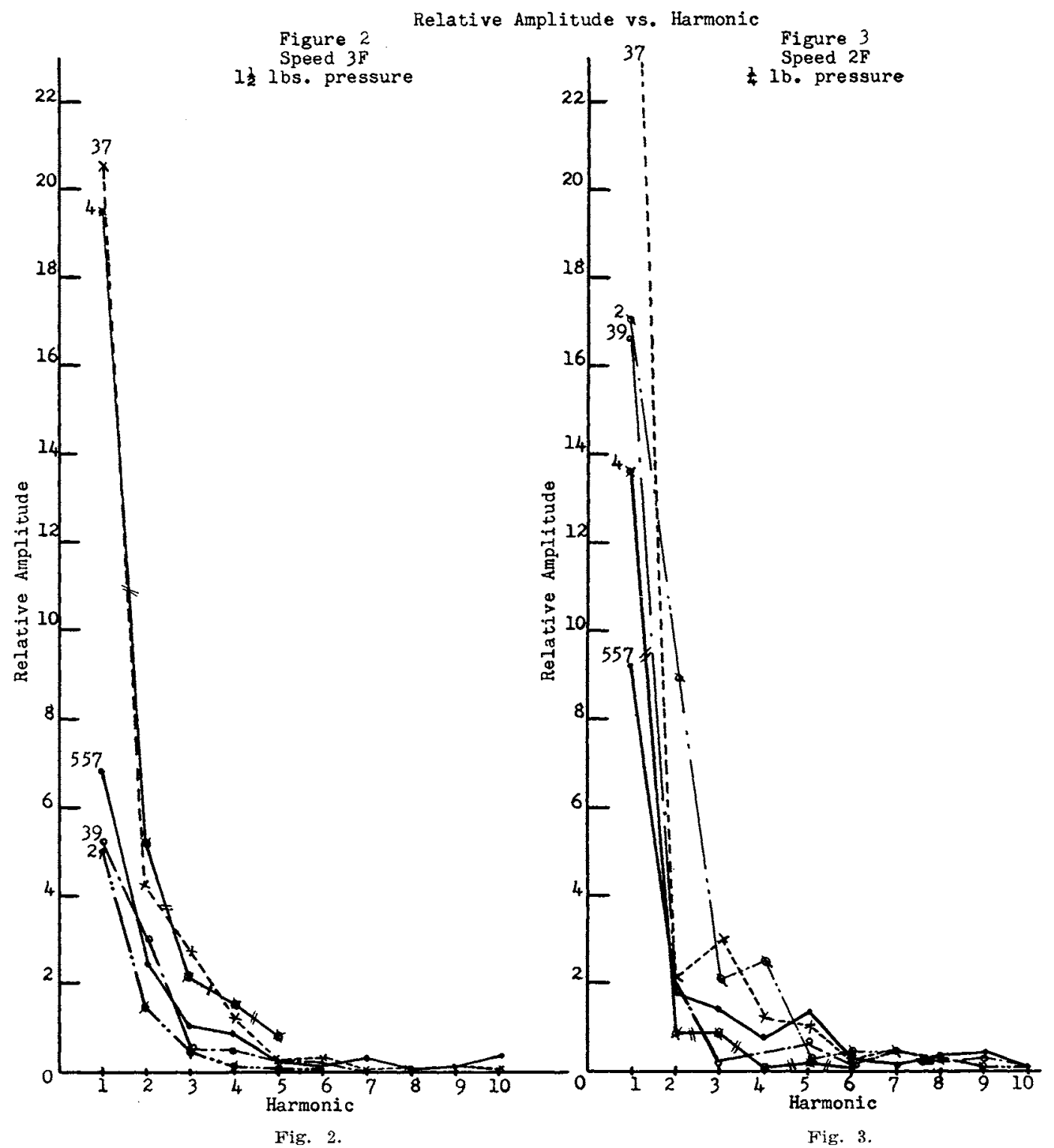

Fig. 2.--Relative amplitude of various vibrations at speed $3 F$ and $1 \frac{1}{2} 1 \mathrm{bs}$. pressure. Fig. 3.-Relative amplitude of various vibrations at speed $2 \mathrm{~F}$ and $1 / 41 \mathrm{~b}$. pressure.

rotation at pressures of $1 / 4$ and $3 / 4 \mathrm{lbs}$. The speed of rotation was calculated from the fundamental frequency of the vibration. When operating at these light pressures, a pronounced tendency is shown for the amplitude of vibration to decrease as the speed is increased. This prevails for both the forward and reverse directions of operation.

With the application of greater pressures of 2 and $3 \mathrm{lbs}$., as shown in Fig. 7 , there is a less pronounced relationship between relative amplitude and speed 


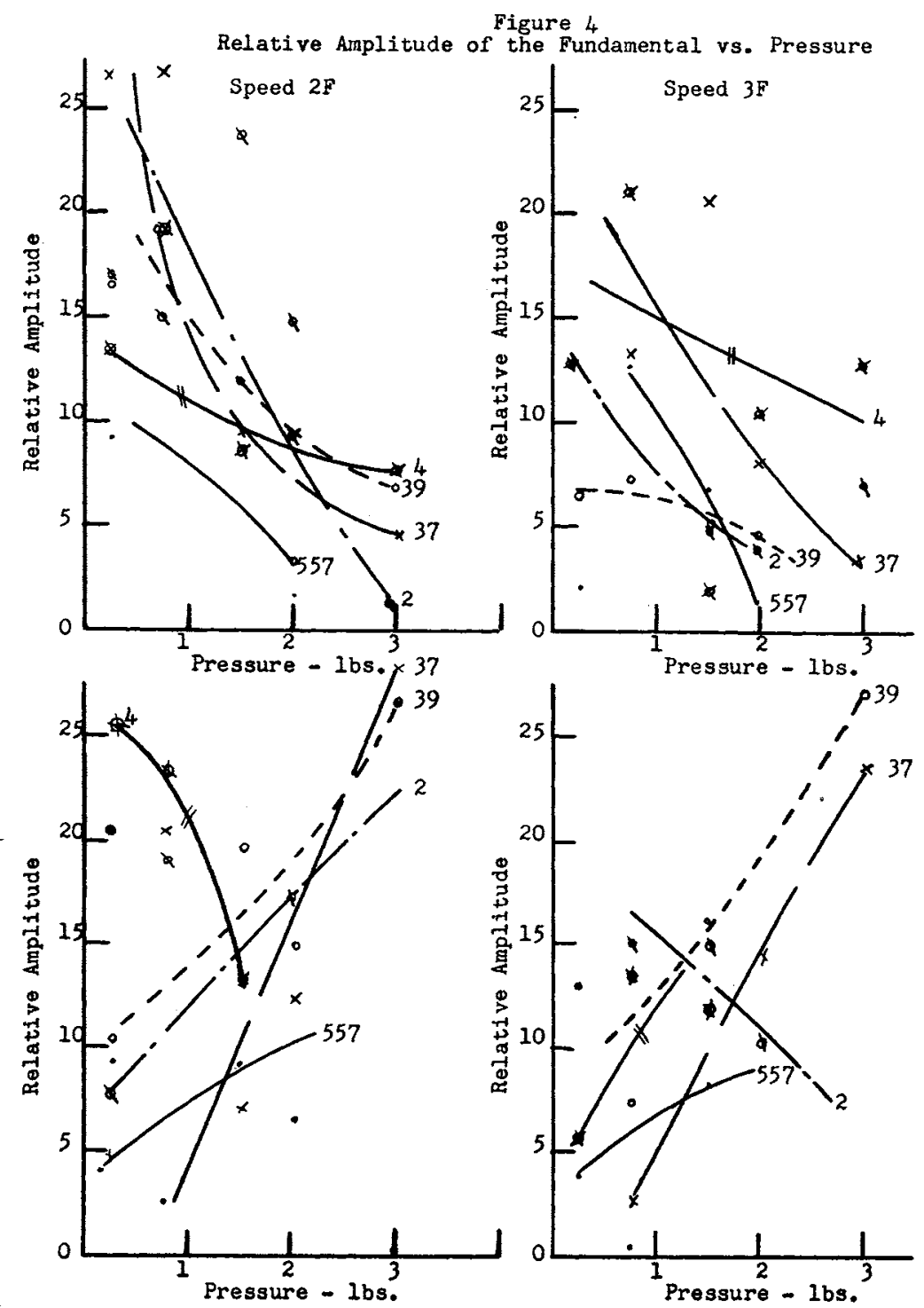

Fig. 4.-Relative amplitudes of fundamental vibrations at various pressures.

of operation. The slopes of the curves, however, are much more gradual at the higher pressures than at the lower pressures represented in Fig. 6. This characteristic, and the lack of agreement in trends at heavier pressures, may be due to several factors, one of which is perhaps the accumulation of chips in the cutting area.

A brief study has been made of the relative amplitude of the third harmonic developed at different speeds with light pressures of operation. These values are shown in Fig. 8. In general, there is a decrease in amplitude with an increase in speed for this third harmonic, which is similar to the trend shown by the fundamental vibration represented in Fig. 6. As pointed out previously, 

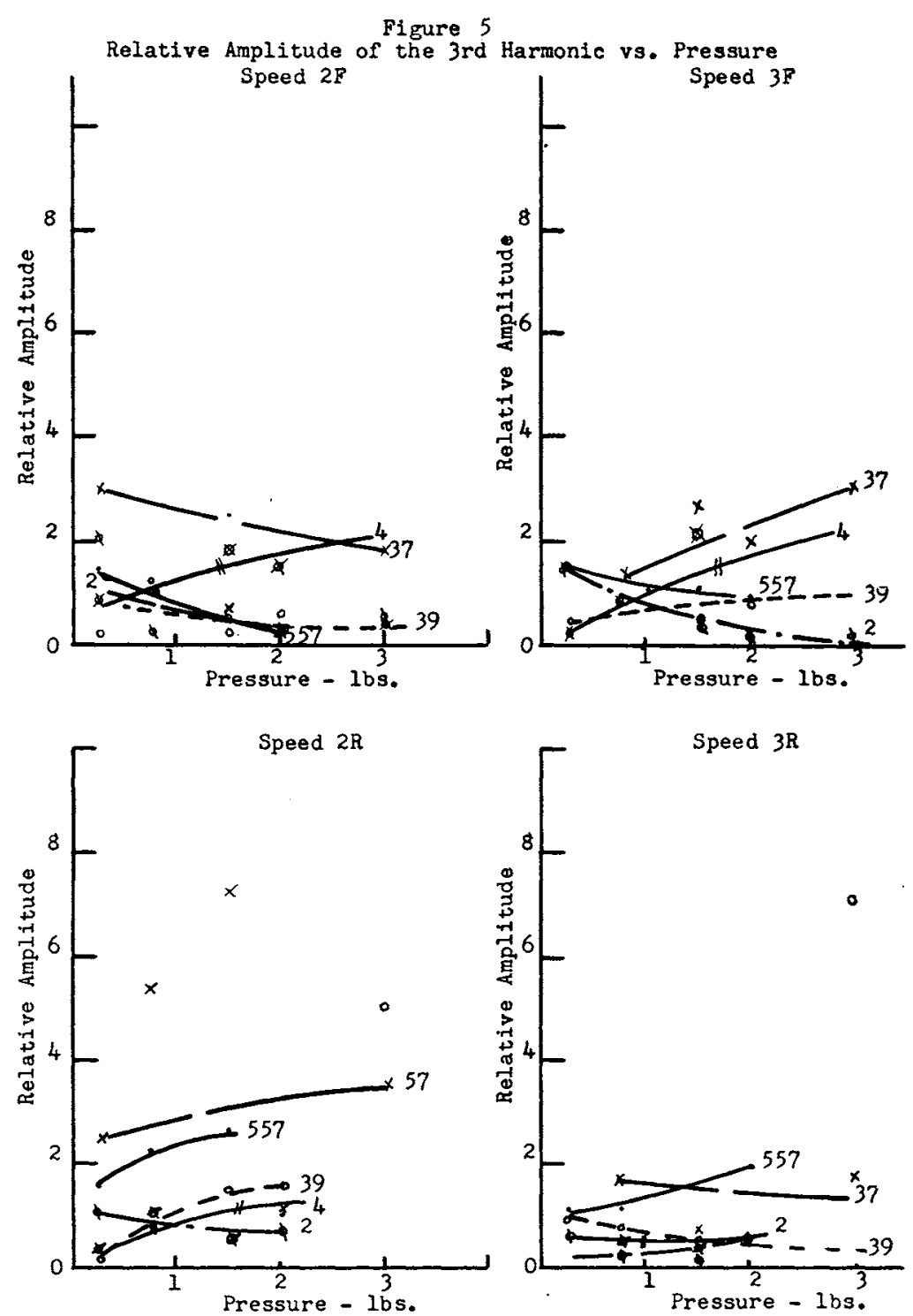

Fig. 5.-Relative amplitudes of third harmonic at different pressures.

however, the relative amplitude of this harmonic is considerably less than that of the fundamental vibration.

Photographs of oscillographic waves are shown in Fig. 9. These waves were produced at a speed of $2 \mathrm{~F}$ and a load of $200 \mathrm{Gm}$. (1/4 $\mathrm{lb}$.) on the handpiece, when using a No. 557 bur, a No. 37 and No. 39 inverted cone bur, and a No. 2 and No. 4 round bur. A photograph of the vibration from an unloaded handpiece operated at the same speed is also included for comparison of the wave shape. No attempt should be made to compare the amplitudes of the wave in each photograph. 
Figure 6
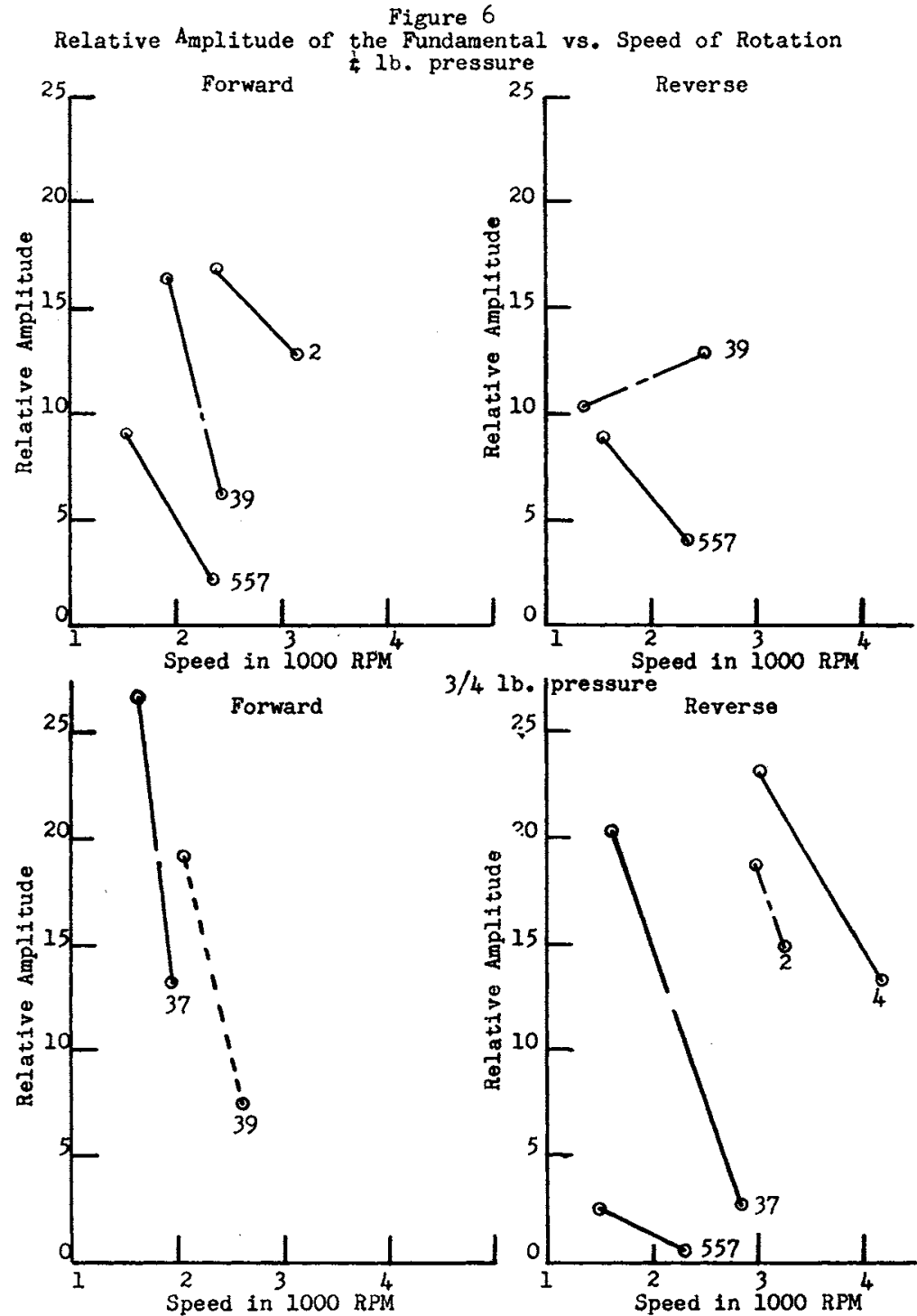

Fig. 6.--Influence of speed at light pressure on relative amplitude.

\section{VIBRATIONS FROM THE AIR-DENT UNIT}

Some study has been made of the vibration characteristies developed from the use of the gas-propelled abrasive to cut tooth tissue with the instrument known as the Air-dent Unit. Using the same method of detecting vibrations as described for the conventional handpiece, the stream of abrasive was directed from different angles toward the block of ivory being cut, on which the needle of the pick up was resting. With the abrasive directed toward the ivory block in such a direction as to be parallel with the plane of maximum sensitivity of the pick up, a relative amplitude of only 0.443 , with a frequency of approximately 
Relative Amplitude of the Fundamental vs. Speed of Rotation

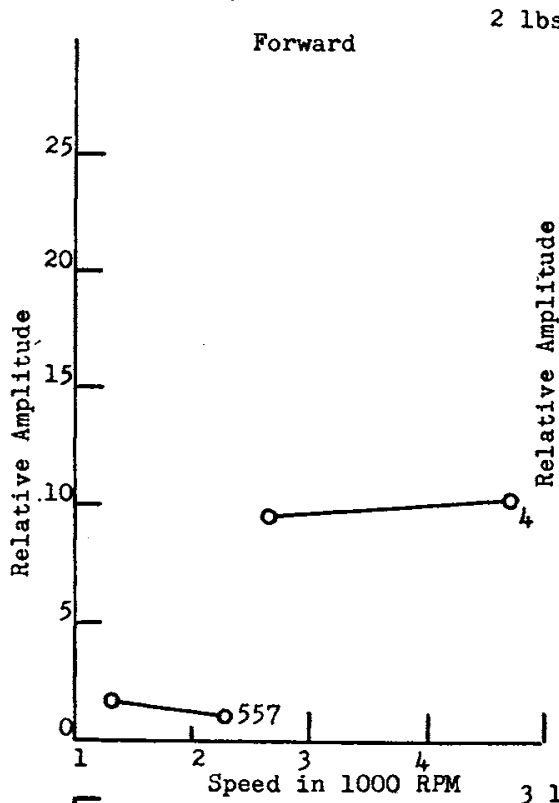

2 lbs. pressure
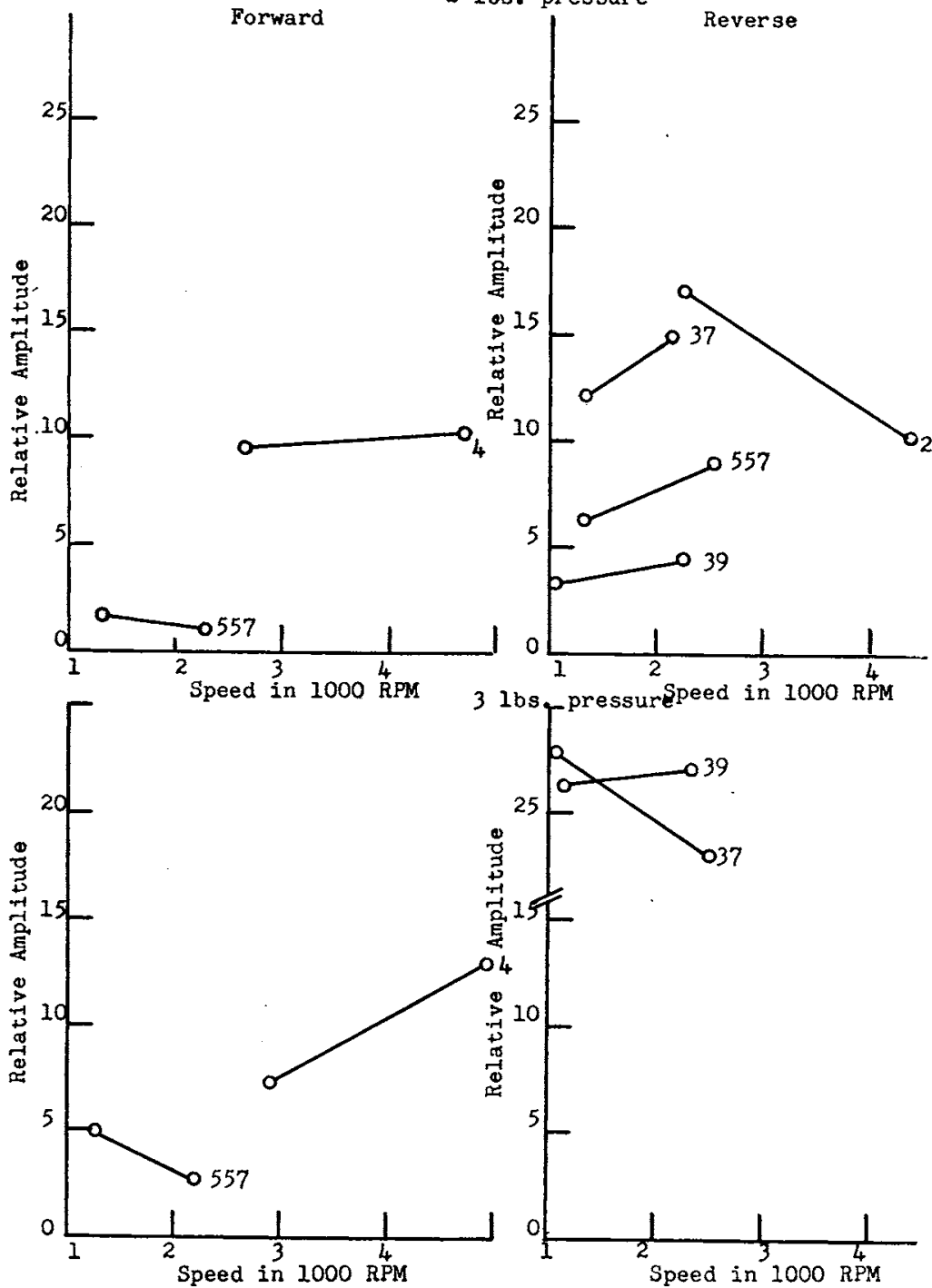

Fig. 7.- Influence of speed at heavy pressure on relative amplitude.

600 C.P.S. was obtained. As a possible source of vibrations during operation, or by comparison with more conventional rotary cutting instruments, it is not considered that this vibration is of practical significance.

\section{DISCUSSION OF RESULTS}

Throughout this study it has been evident that very little information is available to serve as a guide, or as a basis of comparison for values obtained on vibration characteristics. As the study progressed it became increasingly evident that many variable factors of operation must be well controlled if results 
Figure 8

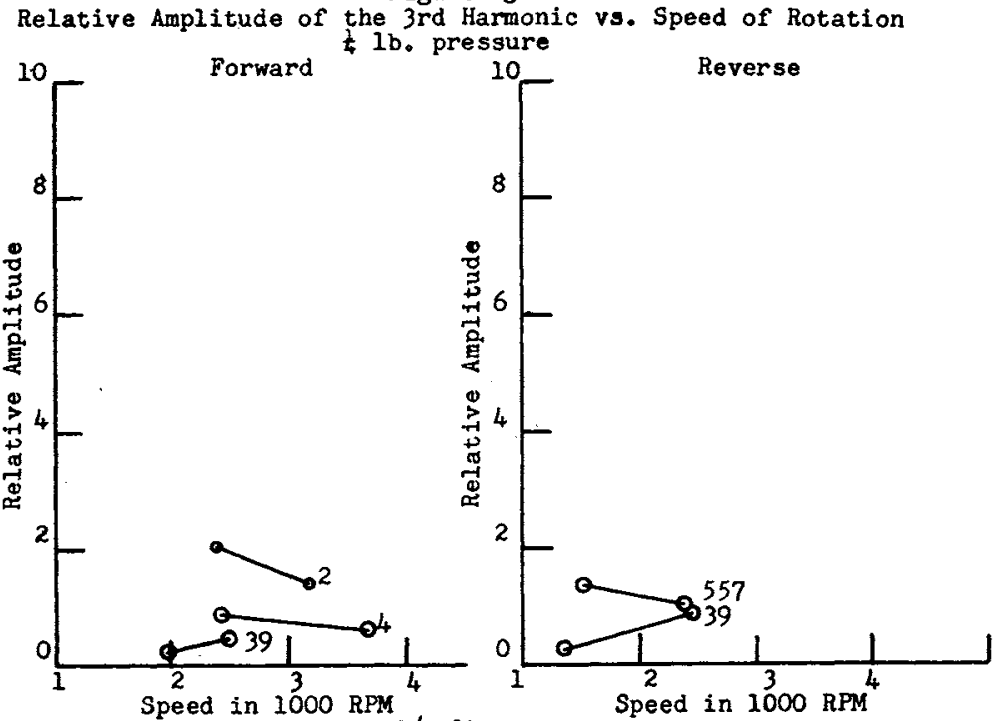

$3 / 4$ 1b. pressure
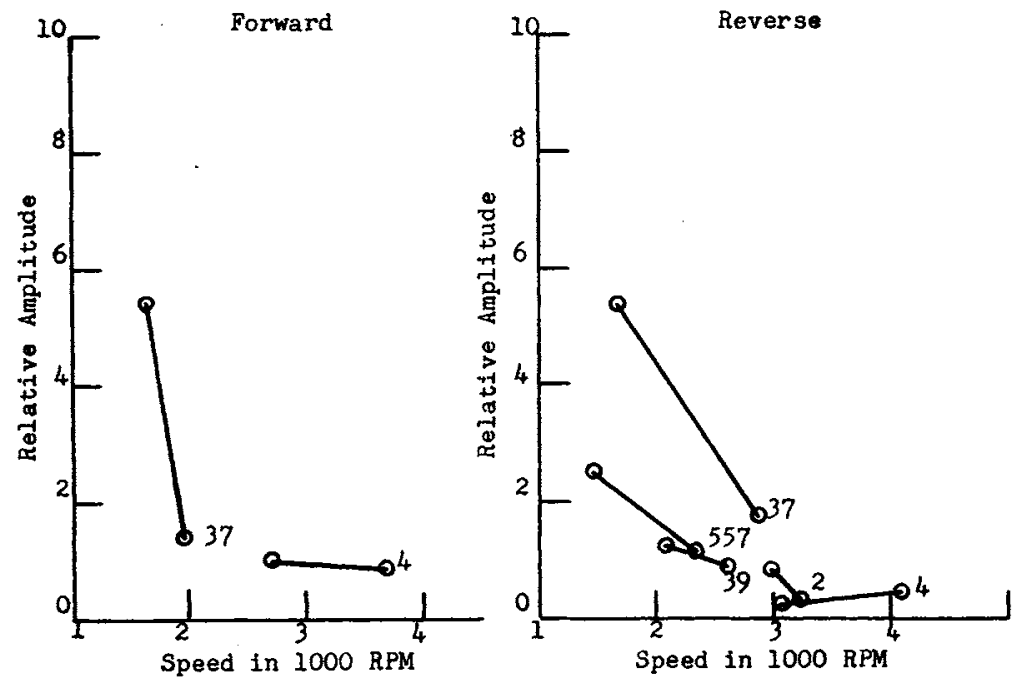

Fig. 8.- Influence of speed at light pressure on third harmonic.

of more than qualitative character are to be obtained. Since the study was initiated there have been several improvements and refinements introduced into the method of detection and measurement of the vibrations produced. It is believed that these alterations in method should make the continuation of this study less difficult in comparing other cutting instruments and conditions of operation.

In this initial report a comparison of only a few steel burs is described, when operated at conventional, relatively slow speeds, and at pressures which prevail at average operating conditions. From an examination of the data and 


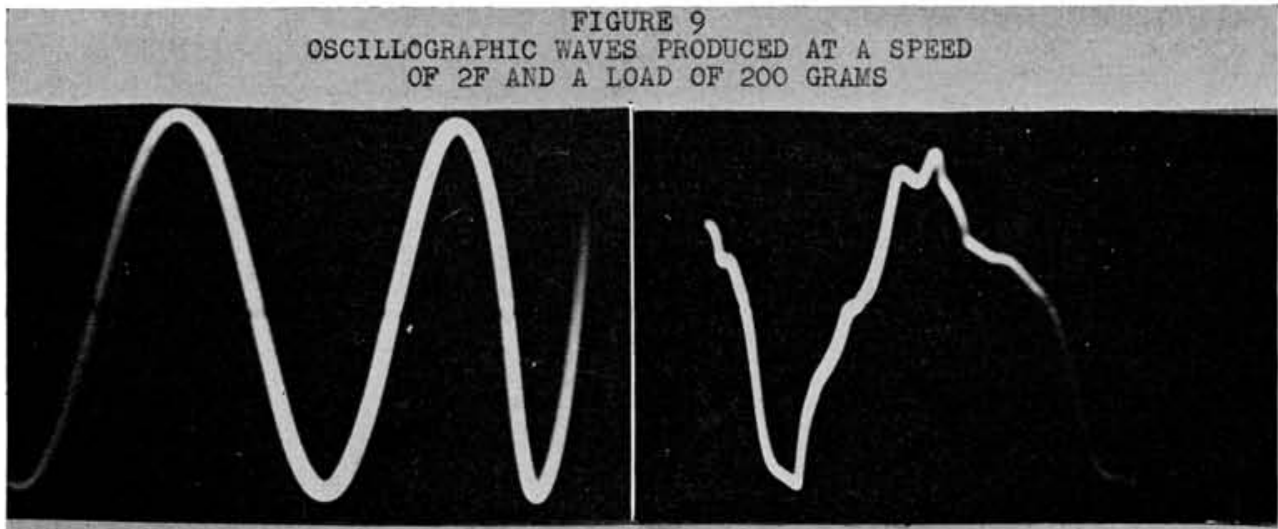

STRAIGHT HANDPIECE WITH NO. 557 BUR

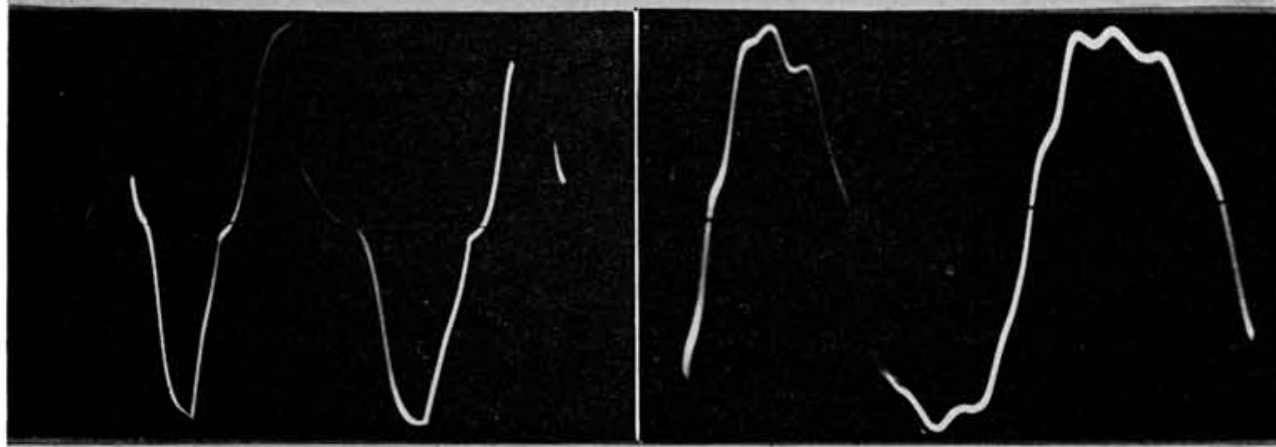

STRAIGHT HANDPIECE WITH NO.37 BUR

STRAIGHT HANDFIECE WITH NO.39 BUR
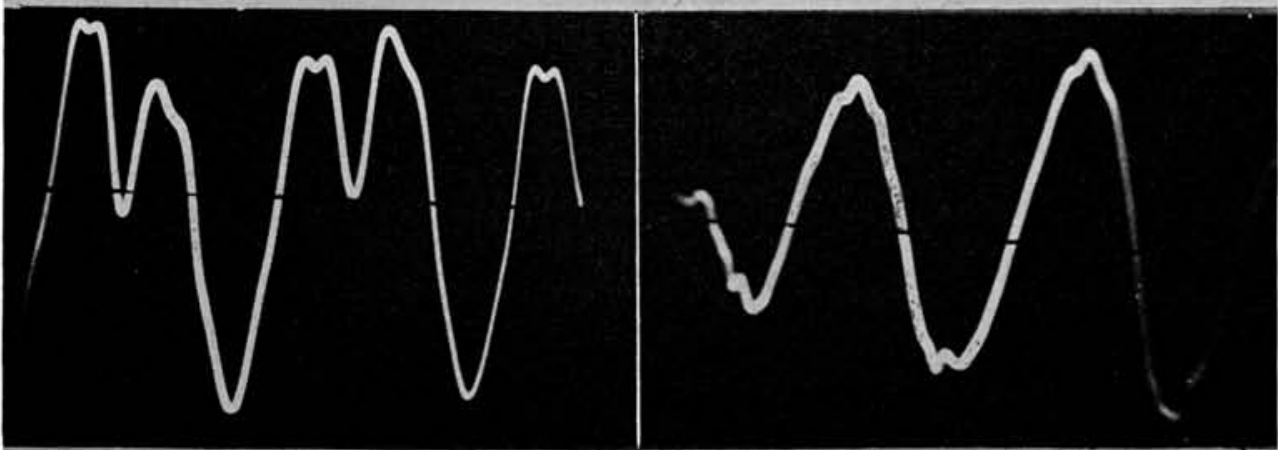

STRAIGHT HANDPIECE WITH NO.2 BUR

STRAIGHT HANDPIECE WITH NO.4 BUR

Fig. 9.-Photographs of oscillograph waves with sine waves.

graphs presented there has been observed, in general, several characteristic trends which appear to exist. It is these trends which have been described in this report.

As the study of vibration characteristics of the handpiece has developed, it has become more evident that in order to understand fully the operating charac- 
teristics of the rotating cutting instrument, the vibration should be correlated with not only the temperature change during cutting, but also with the efficiency of tissue removal of various instruments and conditions of operation. For example, it has been observed, ${ }^{6}$ in the study of thermal ehanges developed during the eutting of tooth tissue, that nearly a linear relationship results in which the temperature change varies directly with either the pressure applied or speed employed. It would seem therefore that there are two compensating influences which exist during the cutting operation. Namely, as the pressure is increased, the vibration is decreased as observed in this study, but at the same time the temperature is increased. At light loads of operation, when the speed is increased the vibration is rapidly decreased, but as the speed is increased the temperature is increased. At heavier pressures, the vibration decrease is less pronounced as the speed is increased, but the rate of thermal change is nearly identical with that of light loads. Hence, from a practical standpoint both the temperature change and vibrations developed must be noted for each condition of operation. In addition, the practical aspect of the amount of tissue removed in any given period of time must be recognized. The instrument which removes the most tooth structure with the least vibration and temperature increase, yet has the longest life in continuous operation, should be the most nearly ideal.

\section{SUMMARY}

Since the results described in this paper represent a portion of the work done on the problem, and since the study is still actively in progress, this should be considered as a preliminary or progress report. The results described were obtained by using the conventional handpiece and rotating dental instruments to eut ivory. The data presented are considered to be applicable only for the test conditions described and, while they perhaps show a trend to be expected when operating on teeth in the mouth, studies will be made to verify the mouth conditions.

In this study certain characteristic trends were observed, and while some specific exceptions were also noted, the prevailing observations justify the establishment of the trends. Throughout the study the fundamental vibration wave has occurred at the speed of rotation of the handpiece shaft and changes with operating speed. The fundamental vibration wave, which is larger than any harmonic, is modified by different operating speeds and pressures, as well as by the choice of cutting instrument employed. In general, the amplitude of the fundamental vibration decreases as the pressure is increased when the bur is driven in the forward direetion. When operating with light pressures there is the tendency for the amplitude of vibration to decrease as the speed is increased. This tendency prevails, but is less pronounced when operating at heavier pressures. In general, the slower speeds and lighter pressures have given the larger amplitude to the fundamental vibration wave, with gradually decreasing amplitudes for the second to fifth harmonies, beyond which the harmonic amplitudes are essentially the same to the tenth. While there is some tendency for larger bur sizes to show a greater vibration characteristic, more studies will be made of this relationship. 


\section{REFERENCES}

1. Gabel, A. B.: Physical Factors in the Production and Control of Dental Pain, Ch. VII, in Control of Pain in Dental Practice, J. L. T. Appleton, editor, Philadelphia, 1940, J. B. Lippincott Company.

Gabel, A. B.: Physical Factors in Production and Control of Pain, J. A. D. A. 27: 1411, 1940.

2. Braceland, F. J.: Psychologic and Psychiatric Aspects of Pain Control, Ch. IV, in Control of Pain in Dental Practice, J. L. T. Appleton, editor, Philadelphia, 1940, J. B. Lippincott Company.

3. Best, E. S.: Elimination of Pain in Dentistry, J. A. D. A. 17: 1481, 1930.

Best, E. S.: Psychology of Pain Control, J. A. D. A. 22: 256, 1935.

4. Pfaffman, Carl: Afferent Impulses From the Teeth Resulting From a Vibratory Stimulus, J. Physiol. 97: 220, 1939.

5. Walsh, J. P., and Symmons, H. F.: Vibration Perception and Frequencies, New Zealand D. J. $45: 106,1949$.

6. Peyton, F. A., and Vaughn, R. C.: Thermal Changes Developed During the Cutting of Tooth Tissue, Fortnightly Review, October 15, 1950. 